\title{
Effect of size and processing method on the cytotoxicity of realgar nanoparticles in cancer cell lines
}

This article was published in the following Dove Press journal:

International Journal of Nanomedicine

| August 20| |

Number of times this article has been viewed

\author{
Weizhong Zhao' \\ Xun Lu \\ Yuan Yuan' \\ Changsheng Liu' \\ Baican Yang ${ }^{3}$ \\ Hua Hong' \\ Guoying Wang ${ }^{3}$ \\ Fanyan Zeng ${ }^{2}$
}

'The State Key Laboratory of Bioreactor Engineering,

${ }^{2}$ Key Laboratory for Ultrafine

Materials of Ministry of Education

and Engineering Research Center

for Biomedical Materials of Ministry

of Education, East China University

of Science and Technology, ${ }^{3}$ Pharmacy

Department of Traditional Chinese

Medicine, Shanghai University

of Traditional Chinese Medicine,

Shanghai, People's Republic of China
Abstract: In this study, the effects of the size and Chinese traditional processing (including elutriation, water cleaning, acid cleaning, alkali cleaning) on realgar nanoparticles ( $R N)$-induced antitumor activity in human osteosarcoma cell lines (MG-63) and hepatoma carcinoma cell lines (HepG-2) were investigated. The human normal liver cell line (L-02) was used as control. RN was prepared by high-energy ball milling technology. The results showed that with the assistance of sodium dodecyl sulfate, the size of realgar could be reduced to $127 \mathrm{~nm}$ after 12 hours' ball milling. The surface charge was decreased from $0.83 \mathrm{eV}$ to $-17.85 \mathrm{eV}$ and the content of $\mathrm{As}_{2} \mathrm{O}_{3}$ clearly increased. Except for elutriation, the processing methods did not clearly change the size of the $\mathrm{RN}$, but the content of $\mathrm{As}_{2} \mathrm{O}_{3}$ was reduced dramatically. In vitro MTT tests indicated that in the two cancer cell lines, RN cytotoxicity was more intense than that of the coarse realgar nanoparticles, and cytotoxicity was typically time- and concentration-dependent. Also, RN cytotoxicities in the HepG-2 and L-02 cells all increased with increasing milling time. Due to the reduction of the $\mathrm{As}_{2} \mathrm{O}_{3}$ content, water cleaning, acid cleaning, and alkali cleaning decreased $\mathrm{RN}$ cytotoxicity in HepG-2, but RN after elutriation, with the lowest $\mathrm{As}_{2} \mathrm{O}_{3}(3.5 \mathrm{mg} / \mathrm{g})$ and the smallest size $(109.3 \mathrm{~nm})$, showed comparable cytotoxicity in HepG-2 to RN without treatment. Meanwhile, RN-induced cytotoxicity in L-02 cells was clearly reduced. Therefore, it can be concluded that RN may provide a strong antiproliferation effect in the MG- 63 and HepG- 2 cells. Elutriation processing is a suitable approach to limit the dangerous side-effects of $\mathrm{As}_{2} \mathrm{O}_{3}$, while maintaining the effectiveness of RN.

Keywords: realgar nanoparticles, cytotoxicity, size, processing, apoptosis

\section{Introduction}

Realgar (Xiong-Huang in Chinese), an arsenic-containing Chinese traditional mineral drug (its major component is $\mathrm{As}_{2} \mathrm{~S}_{2}$ or $\mathrm{As}_{4} \mathrm{~S}_{4}$ ), has been used for treatment of various diseases, such as carbuncles, scalds and burns, insect-bites, abdominal pains, infantile convulsions, and psoriasis, for more than 1500 years. ${ }^{1-4}$ Especially in recent years, with the confirmation of its clinical effectiveness for the treatment of some varieties of refractory or relapsed tumor or cancer, realgar has attracted increasing attention in the biomedical field. ${ }^{5}$ In particular, previous investigations showed that realgar is absorbed rapidly and excreted mostly within the first 24 hours' urine. ${ }^{6}$ Unfortunately, poor natural water solubility and thus poor bioavailability greatly hampers wider clinical applications of realgar. It has been reported that only $0.10 \%$ and $0.40 \%$ of the coarse realgar (CR) powder dissolves in the stomach and intestinal fluids, and is finally absorbed. ${ }^{4}$ Therefore, there is an urgent need for methods to safely and effectively deliver poorly water-soluble realgar. 
Due to its inherent nonionizable property, there is a limited number of chemical approaches available to overcome the disadvantages of realgar. Therefore, realgar nanoparticles $(<100 \mathrm{~nm}$ in diameter) were proposed and several strategies have been used to reduce the size of realgar in the past few years. It has been proved that the physical and chemical properties of realgar and other nanoparticles can be significantly improved or radically changed as their size is scaled down to small clusters of atoms, especially in clinical applications. ${ }^{6}$ The ensuing in vitro and in vivo experiments revealed that the size indeed had dramatic effect on the antitumor activity of realgar. Compared with $\mathrm{CR}$, realgar nanoparticles $(\mathrm{RN})$ exhibited greater toxicity in a cervical cancer cell line (HeLa), three human ovarian cancer cell lines (CI80-13S, OVCAR, OVCAR-3), ${ }^{6}$ and normal ECV-304 cells. ${ }^{7}$ Accordingly, in our previous study, our group also endeavored to prepare $\mathrm{RN}$ by high-energy milling technology. The results revealed that the disintegration of realgar particles was accompanied by an obvious increase in arsenic trioxide $\left(\mathrm{As}_{2} \mathrm{O}_{3}\right)$ from 2.82 to $9.75 \mathrm{mg} / \mathrm{g}$. Research has shown that inorganic $\mathrm{As}_{2} \mathrm{O}_{3}$ is the most toxic arsenic species and can induce complete remission in a high percentage of patients with refractory acute promyelocytic leukemia. ${ }^{8-11}$ However, the high toxicity and severe side effects, especially in long-term use, make it unacceptable in clinic settings. ${ }^{12}$ That is to say, reduction of the $\mathrm{As}_{2} \mathrm{O}_{3}$ content of $\mathrm{RN}$ should be considered prior to clinical use.

Processing is a widely used method to reduce the toxicity of traditional Chinese medicines. The most commonly used processing methods include elutriation, water cleaning, acid cleaning, and alkali cleaning. To date, the effects of these processing methods on the $\mathrm{As}_{2} \mathrm{O}_{3}$ content and the change in resulting antitumor activity have never been investigated.

In this study, our first objective was to prepare $\mathrm{RN}$ and investigate the cytotoxicity of the prepared $\mathrm{RN}$ in human osteosarcoma cell lines (MG-63) and human hepatoma carcinoma cell lines (HepG-2), which has not been reported previously. Our second objective was to study the effect of processing method (elutriation, water cleaning, acid cleaning, and alkali cleaning) on the physicochemical properties and cytotoxicity of RN in MG-63 and HepG-2 cell lines. The cytotoxicity of RN in human normal liver cell line was also investigated for comparison, and the potential apoptosis induction of $\mathrm{RN}$ particles after processing was investigated, too. $\mathrm{RN}$ were prepared by high-energy milling technology with the help of sodium dodecyl sulfate (SDS) at room temperature. The cytotoxicity was evaluated by MTT assay.

\section{Materials and methods Materials}

Realgar $\left(\mathrm{As}_{2} \mathrm{~S}_{2}, 98 \%\right.$ in purity) was purchased from Hubei Province. Arsenic trioxide $\left(\mathrm{As}_{2} \mathrm{O}_{3}\right)$ was kindly provided by Zhongshan Hospital. SDS (Junsei, Japan) has been used previously in milling tests as a surfactant. MG-63, HepG-2, and L-02 cell lines were purchased from the American Type Culture Collection (ATCC).

\section{Methods}

\section{Preparation of RN by high-energy ball milling}

The ball milling equipment (Nanjing University Instrument Plant, Nanjing, China) was used to reduce the particle size of realgar powder. There were four grinding vials in the equipment and pure realgar powder $(5.0 \mathrm{~g})$ was also added with SDS aqueous solution (saturated concentration) to each vial. The rate of milling ball and realgar was $\mathrm{W}$ (balls)/ $\mathrm{W}($ realgar $)=40 / 1$ and rate of rotation was $400 \mathrm{rpm}$. These four realgar preparations were ground simultaneously to produce particles under the same operating conditions. In order to study how the process altered RN size, three ballmilling times were chosen: 4,8 , and 12 hours.

\section{Processing methods of the as-prepared RN}

The as-prepared RN was processed by the following four methods: elutriation, water cleaning, acid cleaning, and alkali cleaning. The corresponding RN obtained were named E-RN, WC-RN, ACI-RN, and ALK-RN, respectively.

1. Elutriation: $10 \mathrm{~g}$ RN powder and $5 \mathrm{~mL}$ distilled water were first added into a mortar. After 5 minutes' grinding, $100 \mathrm{~mL}$ distilled water was added and then agitated for 1 minute. The solution stood for 10 minutes, then the clear supernatant liquid was collected and the coarse powder remaining was ground again. This procedure was repeated eleven times to obtain E-RN.

2. Water cleaning: $10 \mathrm{~g} \mathrm{RN}$ powder and $100 \mathrm{~mL}$ distilled water were added to a beaker and agitated for 30 minutes. Sucking filtration was then carried out and the processed $\mathrm{RN}$ were collected. This procedure was repeated eleven times to obtain WC-RN.

3. Acid cleaning: $10 \mathrm{~g} \mathrm{RN}$ powder and $100 \mathrm{~mL}$ dilute hydrochloric acid solution were added to a beaker and agitated for 30 minutes. Sucking filtration was then carried out and the $\mathrm{RN}$ processed was collected. This procedure was repeated eleven times to obtain ACI-RN.

4. Alkali cleaning: $10 \mathrm{~g}$ RN powder and $100 \mathrm{~mL}$ dilute caustic soda solution (3\%) were added to a beaker and 
agitated for 30 minutes. Sucking filtration was then carried out and the RN processed was collected. This procedure was repeated eleven times to obtain ALK-RN.

\section{Characterization}

X-ray diffraction measurement (XRD, D/max 2550 VB/PC; Rigaku, Tokyo, Japan) and Fourier transform infrared spectrometer (Nicolet-5700 FTIR; Nicolet, Waltham, MA) were used to study the changes in phase and chemical composition of the RN. XRD was carried out by using a diffractometer X Perth MPD working in the $2 \theta$ geometry with $\mathrm{Cu} \mathrm{K} \alpha$ radiation at room temperature. Measurements were done at $40 \mathrm{kV}$ voltage, $40 \mathrm{~mA}$ current, and a scanning angle $(2 \theta)$ range $0^{\circ}$ to $90^{\circ}$.

Particle size distribution and zeta potential were determined by a Zetasizer (Mastersizer 2000; Malvern Instruments, Malvern, UK). The testing conditions were as follows: the dispersal medium was ultrapure water; RN concentration was $0.25 \mathrm{mg} / \mathrm{mL}$; the suspension was sonicated for 5 minutes before measuring; and each different milling time condition of the realgar filtrate was analyzed and compared. A scanning electron microscope (JEM-2010 HR SEM; JOEL, Tokyo, Japan) was used to examine the morphology of the ground $\mathrm{RN}$ and also to physically measure the size of the ground $\mathrm{RN}$.

\section{Assay of the $\mathrm{As}_{2} \mathrm{O}_{3}$ content}

$\mathrm{As}_{2} \mathrm{O}_{3}$ content was assayed by the classical Ag-DDC method. In brief, arsenic was reduced by $\mathrm{Zn}$ into arsenic trihydride in a solution of dissolved potassium iodide and stannous chloride. Then the arseniuretted hydrogen was passed through the lead acetate solution in order to remove hydrogen sulfide in the gas, and the remaining pure gas was passed through silver diethyldithiocarbamate-triethanolamine-trichloromethane mixed solution. $\mathrm{The} \mathrm{Ag}^{+}$was then reduced to red colloidal silver, and the absorbance of colloidal silver was compared with the standard arsenic solution to assay the content of elemental As.

\section{Cytotoxicity determination}

In this study, MG-63, HepG-2, and L-02 cells were used to test the cytotoxicity of the RN. Three cell lines were cultured in $37.5 \mathrm{~cm}^{2}$ flasks with growth medium (Dulbecco's modified Eagle's medium (GIBCO, Grand Island, NY) containing $10 \%$ fetal calf serum (Sijiqing, Hangzhou, China), antibiotics (100 U/mL penicillin-G, $100 \mathrm{mg} / \mathrm{mL}$ streptomycin) at $37^{\circ} \mathrm{C}$ in humidified atmosphere of $5 \% \mathrm{CO}_{2} / 95 \%$ air until confluence, then detached with $0.25 \%$ trypsin $/ 0.03 \%$ ethylenediamine tetraacetic acid (EDTA) and the cell density was calculated.

These cells were preincubated in 96-well plates at a density of 5000 cells/well. After 24 hours, the cells were treated with different concentrations of $\mathrm{RN}$ for a determined time (24, 48, and 72 hours). Then, the 3-(4,5-dimethylthiazol2-yl)-2,5-diphenyltetrazolium bromide (MTT) labeling solution was added onto the plates containing the RN-treated MG-63, HepG-2, and L-02 cells. After further incubation for 4 hours, the cells were lysed and the purple formazan crystals were solubilized for detection at $570 \mathrm{~nm}$.

\section{Flow cytometry analysis of apoptosis}

\section{and cell cycle distribution}

Based on the cytotoxicity tests for RN, apoptosis was identified and quantified by flow cytometry using HepG-2 cell lines. Cells were treated with various RN for 24 hours. At the end of the incubation, all cells were collected and fixed in $70 \%$ ice-cold ethanol at a cell density of $1 \times 10^{6} / \mathrm{mL}$, and kept at $4^{\circ} \mathrm{C}$ at least overnight until analysis. Fixed cells were washed twice with PBS buffer and treated with $1 \mathrm{mg} / \mathrm{mL}$ RNAse (DNAse-free) (Sigma Chemical Co Ltd, Shanghai, China) for 30 minutes at $37^{\circ} \mathrm{C}$. Propidium iodine (polydispersity index $[\mathrm{PI}] \geq 95 \%$ in purity, Sigma) was then added to the solution at a final concentration of $50 \mu \mathrm{g} / \mathrm{mL}$ and subjected to flow cytometry.

\section{Statistical analysis}

Statistical analysis was performed using SPSS software (v 11.0; SPSS, Inc, Chicago, IL). Significant difference between two groups was evaluated by Student's $t$-test and the level of significance was set at $P<0.05$.

\section{Results RN preparation}

In order to achieve optimal grinding of the realgar, the main experimental conditions, including milling time and concentration of added SDS, were first optimized. Figure 1 shows the size of the RN after 4, 8, and 12 hours grinding with the SDS concentration at $2.48 \mathrm{~g} / \mathrm{L}$, which is the saturated concentration of SDS. Figure 1 clearly shows that average $\mathrm{RN}$ particle size declined as milling time increased. After 4 and 8 hours' milling, RN with average diameters of $469 \mathrm{~nm}$ and $327 \mathrm{~nm}$ were obtained. After 12 hours, the effective diameter of the powders was reduced to $127 \mathrm{~nm}$. Further increased milling time did not decrease particle size further.

With the assistance of SDS, the mean particle sizes were greatly decreased, especially with $2.48 \mathrm{~g} / \mathrm{mL} \mathrm{SDS}$, 


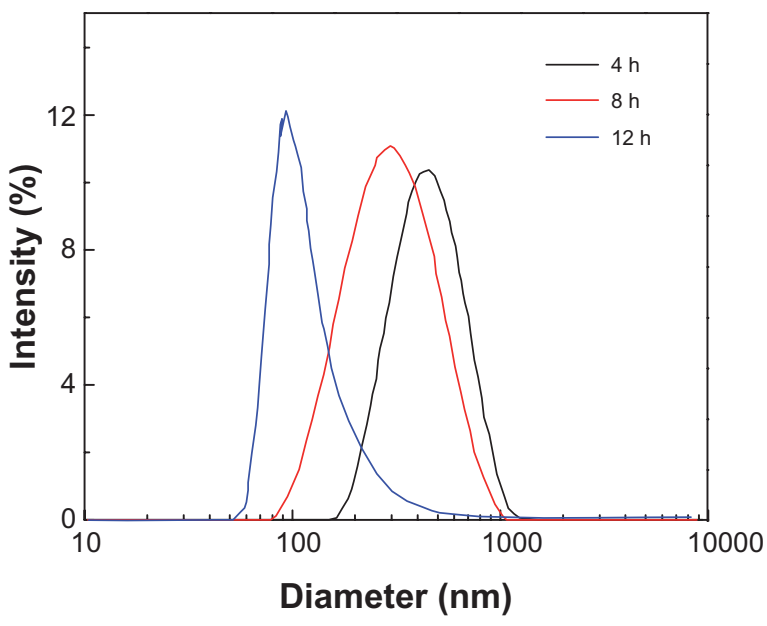

Figure I Particle size distribution of the realgar nanoparticles milled with sodium dodecyl sulfate for 4,8 , and 12 hours.

to $<200 \mathrm{~nm}$. In addition, PI, which represents the pattern of systematic particle distribution, of the co-ground preparations was significantly lower than that of the ground realgar alone, suggesting that the particle distribution became more homogeneous after grinding with additive(s) (Table 1).

These results led to the selection of a milling time of 12 hours and an SDS concentration of $2.48 \mathrm{~g} / \mathrm{mL}$ for the subsequent preparation of RN. Figure 2 displays the representative image of the RN prepared at the optimal conditions. The morphologies of the prepared $\mathrm{RN}$ were irregular and the size ranged from $100 \mathrm{~nm}$ to $300 \mathrm{~nm}$.

\section{Characterization of the as-prepared RN}

After determining the main conditions, we investigated the changes of the phase and chemical compositions, and the surface potential after milling. The results are presented in Figures 3 and 4, and Table 2. The characterized diffraction

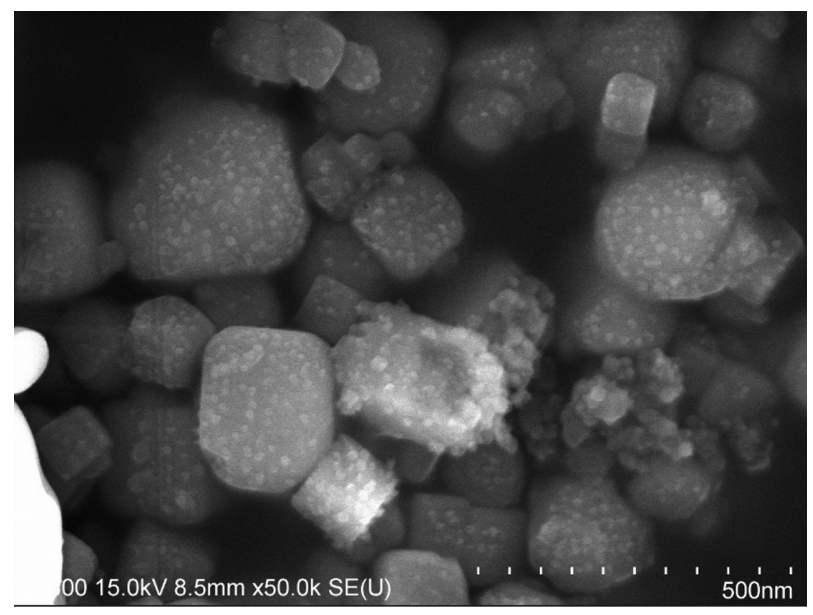

Figure 2 Representative SEM image of the realgar nanoparticles milled for 12 hours.

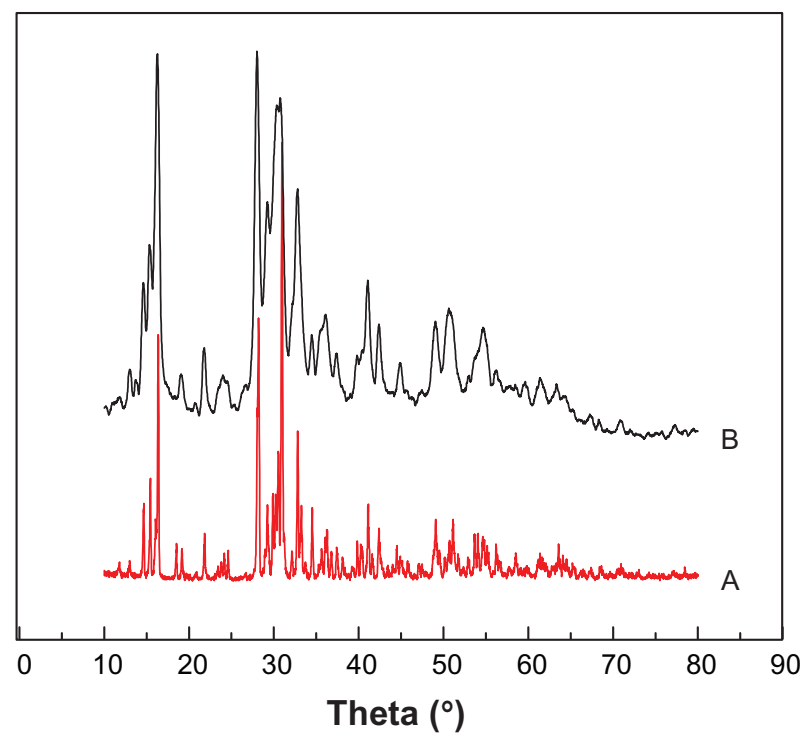

Figure 3 X-ray diffraction patterns of realgar: (A) untreated sample, (B) milled with sodium dodecyl sulfate for 12 hours.

peaks observed in the $\mathrm{RN}$ were in agreement with that of the original realgar powder (Figure 3). The XRD patterns showed a lot of overlapping peaks and the peaks were very close to those filed in the JCPDS card file (No. 09-0441) for $\alpha-\mathrm{As}_{2} \mathrm{~S}_{2}$ crystal. Also, the sharp diffraction peaks indicated good crystallization of the as-prepared $\mathrm{As}_{2} \mathrm{~S}_{2}$ nanocrystals. In addition, a relatively higher background was observed, meaning that a small amorphous fraction was probably present in the sample as a consequence of high-energy milling. The results confirmed that the selected high-energy milling technique did not obviously change the crystallinity of the realgar powder.

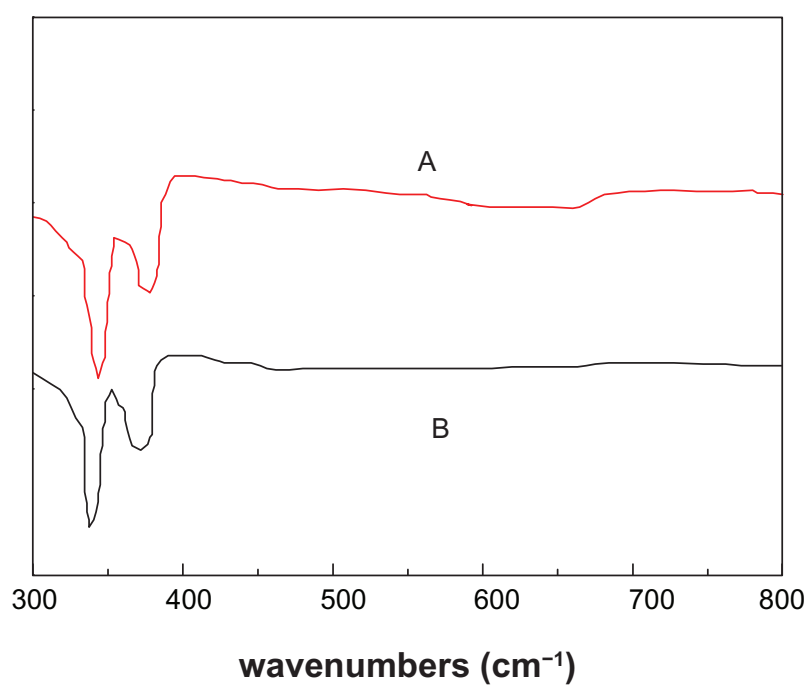

Figure 4 Fourier infrared transform patterns of different types of realgar $(\mathbf{A})$ crude realgar, (B) realgar nanoparticles milled for 12 hours. 
Table I Particle size of realgar nanoparticles milled with different sodium dodecyl sulfate (SDS) concentrations

\begin{tabular}{lll}
\hline & Size $(\mathbf{n m})$ & Polydispersity index \\
\hline Crude realgar & - & $0.892 \pm 0.145$ \\
Realgar milled without additive & $328.3 \pm 3.7$ & $0.522 \pm 0.095$ \\
SDS at $1.24 \mathrm{~g} / \mathrm{L}$ & $249.8 \pm 5.3$ & $0.493 \pm 0.213$ \\
SDS at $2.48 \mathrm{~g} / \mathrm{L}$ & $127.5 \pm 4.6$ & $0.242 \pm 0.103$ \\
\hline
\end{tabular}

Similarly, from the comparison of FTIR spectra of the RN and CR (Figure 4) it can be seen that after ball milling, the characteristic absorption bands corresponding to the realgar peak at about $343-344 \mathrm{~cm}^{-1}$ and $375-376 \mathrm{~cm}^{-1}$ did not change significantly. That is to say, the ball-milling process has little apparent effect on chemical compositions. However, the content of $\mathrm{As}_{2} \mathrm{O}_{3}$ as determined by Ag-DDC assay indicates that after grinding with and without the addition of SDS, the content of $\mathrm{As}_{2} \mathrm{O}_{3}$ increased from $2.82 \mathrm{mg} / \mathrm{g}$ to $11.25 \mathrm{mg} / \mathrm{g}$ and $9.75 \mathrm{mg} / \mathrm{g}$, respectively.

The zeta potential values of the original realgar powder and realgar ground particles without SDS were almost zero (Table 2). After grinding in the presence of SDS, the zeta potential values decreased to $-17.85 \mathrm{mV}$.

\section{Effect of the processing method on RN physicochemical properties}

Table 2 shows that, apart from elutriation, the processing method had no apparent effect on the particle size and the PI of the as-prepared RN. Clearly, after elutriation, RN not only became smaller, but was also distributed more homogeneously.

The results also indicate that $\mathrm{As}_{2} \mathrm{O}_{3}$ content in $\mathrm{RN}$ after all processing methods significantly decreased, except for alkali cleaning, after which $\mathrm{As}_{2} \mathrm{O}_{3}$ content increased after processing. In contrast, elutriation reduced $\mathrm{As}_{2} \mathrm{O}_{3}$ level to $6.25 \mathrm{mg} / \mathrm{g}$, the minimum level achieved, meaning that elutriation was the most effective method of removing $\mathrm{As}_{2} \mathrm{O}_{3}$ in RN.

\section{Cytotoxicity of prepared RN}

The potential in vitro cytotoxicity of the various $\mathrm{RN}$ in the MG-63, HepG-2 cells is shown in Figures 5 and 6. It can be seen that $\mathrm{CR}$ and $\mathrm{RN}$ all had a cytotoxic effect in the MG-63 and HepG-2 cells. In contrast, in both HepG-2 cells and MG-63 cells, RN cytotoxicity at all times was remarkably higher than that of the CR in the tested range of $25-400 \mu \mathrm{g} / \mathrm{mL}$. That is to say, RN cytotoxicity was more intense than that of the CR. In addition, cell viabilities of HepG-2 cells and MG-63 cells all decreased dramatically with increases in time and concentration in a typical time- and concentrationdependent manner (Figures 5 and 6). It is worthwhile noting that the $\mathrm{IC}_{50}$ of the HepG-2 cells and MG-63 cells after 72 hours was $45.2 \mu \mathrm{g} / \mathrm{mL}$ and $52.5 \mu \mathrm{g} / \mathrm{mL}$, respectively. That is, HepG-2 cells were likely more sensitive to RN than MG-63 cells.

After exposure to $\mathrm{RN}$ for 72 hours at a concentration of $400 \mu \mathrm{g} / \mathrm{mL}$, the viabilities of HepG-2 and L-02 cells all decreased with length of milling time. In contrast, $\mathrm{RN}$ exhibited significantly higher cytotoxicity in HepG-2 cells than in L-02 cells $(P<0.05)$ (Figure 7).

\section{Effect of processing on RN cytotoxicity}

As with untreated RN, RN cytotoxicity after different processing methods all increased with increasing concentration (Figure 8). In contrast, the efficacy of antitumor activity decreased in the order of untreated RN $>$ ALK-RN $>$ WC$\mathrm{RN}>\mathrm{ACI}-\mathrm{RN}>\mathrm{E}-\mathrm{RN}$. It is worth noting that, compared with $\mathrm{RN}$ treated by other processing methods, E-RN of the smallest size and the lowest $\mathrm{As}_{2} \mathrm{O}_{3}$ content exhibited the strongest cytotoxicity in HepG-2 cells, almost as high as that of unprocessed RN at high concentration (Figure 9).

After 72 hours' cultivation at $400 \mu \mathrm{g} / \mathrm{mL}$, compared with $\mathrm{RN}$ without processing, cytotoxicity of E-RN in HepG-2 was almost unchanged, but the viability of L-02 clearly increased from $85.2 \%$ to $95.4 \%$, comparable with the $96 \%$ viability after treatment by $\mathrm{CR}$ at the same concentration and for the same time.

Table $2 \mathrm{As}_{2} \mathrm{O}_{3}$ content in realgar nanoparticles (RN) and zeta potential treated by different processing methods

\begin{tabular}{lllll}
\hline & $\begin{array}{l}\text { Size } \\
(\mathbf{n m})\end{array}$ & $\begin{array}{l}\text { Polydispersity } \\
\text { index }\end{array}$ & $\begin{array}{l}\text { Zeta potential } \\
(\mathbf{m V})\end{array}$ & $\begin{array}{l}\mathbf{A s}_{\mathbf{2}} \mathbf{O}_{3} \text { content } \\
(\mathbf{m g} / \mathbf{g})\end{array}$ \\
\hline Crude realgar & - & $0.892 \pm 0.145$ & $0.83 \pm 0.3$ & 2.82 \\
Realgar milled without additive & $328.4 \pm 3.7$ & $0.522 \pm 0.095$ & $0.93 \pm 0.5$ & 1.25 \\
RN with SDS & $127.5 \pm 4.6$ & $0.172 \pm 0.103$ & $-17.85 \pm 1.7$ & 9.75 \\
Elutriation & $109.3 \pm 3.7$ & $0.105 \pm 0.112$ & $-18.01 \pm 2.3$ & 3.50 \\
Water cleaning & $124.2 \pm 4.1$ & $0.195 \pm 0.098$ & $-16.94 \pm 1.8$ & 5.66 \\
Acid cleaning & $129.6 \pm 4.9$ & $0.167 \pm 0.093$ & $-16.77 \pm 1.1$ & 4.75 \\
Alkali cleaning & $133.6 \pm 5.6$ & $0.170 \pm 0.094$ & $-17.1 \pm 1.9$ & 9.26 \\
\hline
\end{tabular}


A

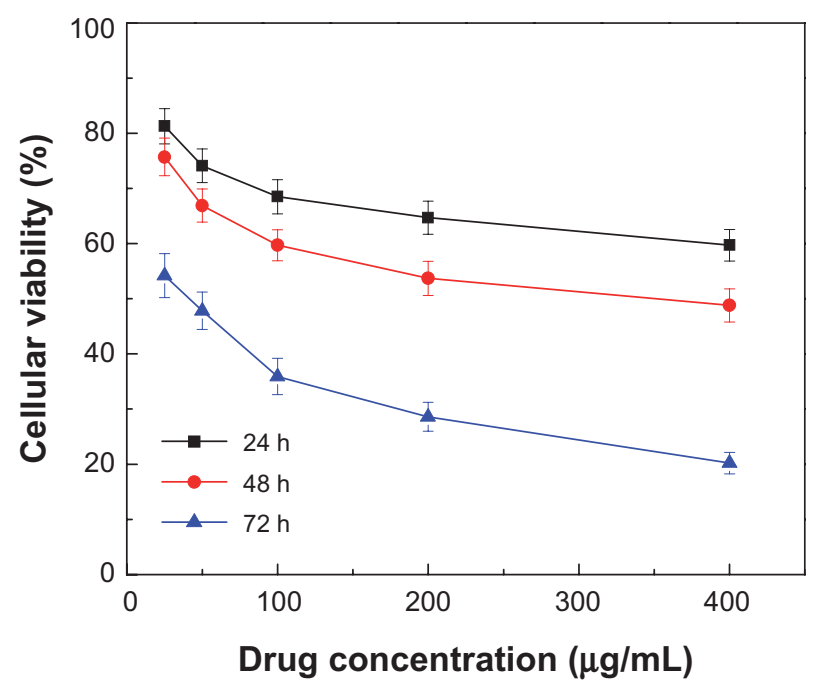

B

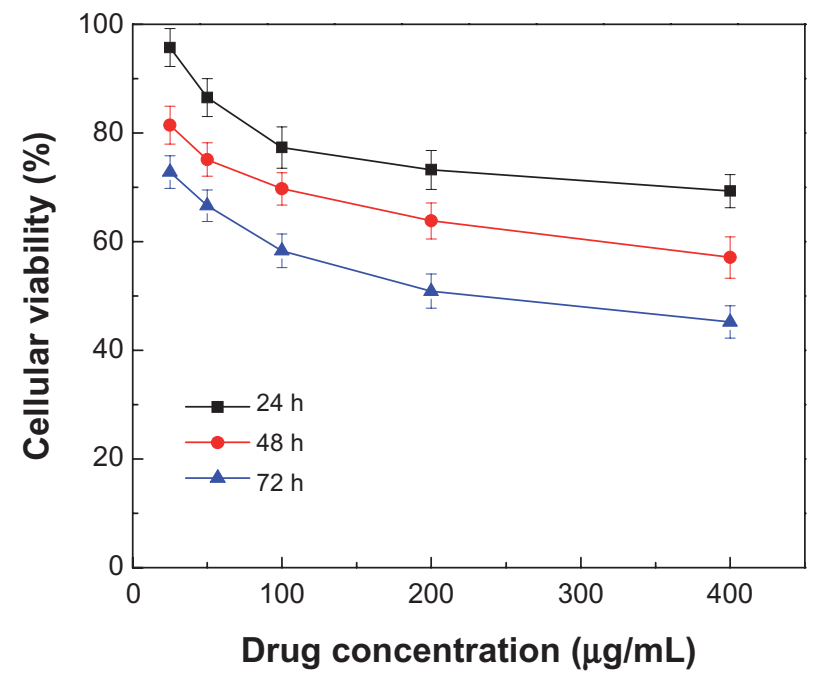

Figure 5 Effect of realgar nanoparticles (RN) on viability of HepG-2 cells. Various concentrations of $R N(A)$ and crude realgar (B) were added to the media: $400 \mu \mathrm{g} / \mathrm{mL}$, $200 \mu \mathrm{g} / \mathrm{mL}, 100 \mu \mathrm{g} / \mathrm{mL}, 50 \mu \mathrm{g} / \mathrm{mL}, 25 \mu \mathrm{g} / \mathrm{mL}$.

\section{Effects of RN treated by different processing methods on apoptosis induction in HepG-2 cells}

Hardly any apoptotic cells were detected in the control group (Figure 10). However, in RN-treated groups, a large number of cells undergoing apoptosis were detected, showing that RN can induce high apoptosis in HepG-2 cells.

After incubation with RN at a concentration of $400 \mu \mathrm{g} / \mathrm{mL}$ for 24 hours, flow cytometry analysis of DNA content showed that the percentages of cells undergoing apoptosis were $4.19 \%, 59.32 \%, 52.87 \%, 56.71 \%, 54.52 \%$, and $62.5 \%$, for the control group, $\mathrm{RN}$, elutriation, water cleaning, acid cleaning, and alkali cleaning treatments, respectively. However, there

\section{A}

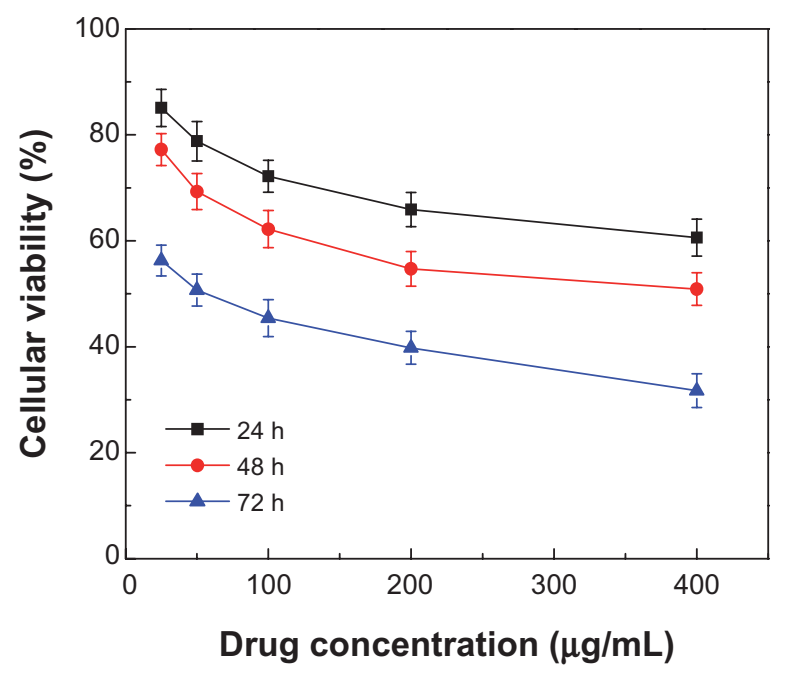

B

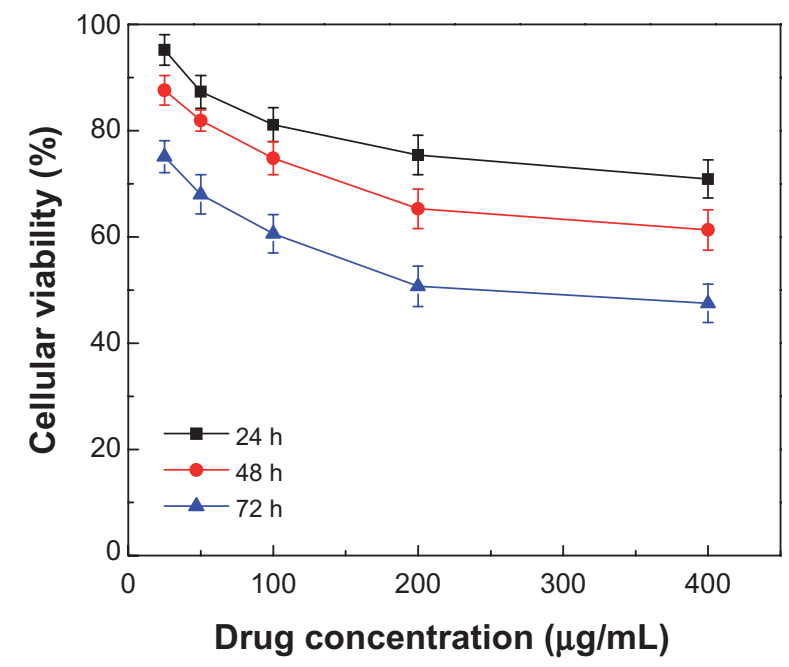

Figure 6 Effect of realgar nanoparticles (RN) on viability of MG-63 cells. Various concentrations of $\mathrm{RN}(\mathbf{A})$ and crude realgar (B) were added to the media: $400 \mu \mathrm{g} / \mathrm{mL}$, $200 \mu \mathrm{g} / \mathrm{mL}, 100 \mu \mathrm{g} / \mathrm{mL}, 50 \mu \mathrm{g} / \mathrm{mL}, 25 \mu \mathrm{g} / \mathrm{mL}$.

was a minor difference between the values of cells in the late stage of apoptosis.

\section{Discussion}

Recently, RN have received substantial attention since their successful clinical application for the treatment of hematopoietic malignancies, especially for acute promyelocytic leukemia. In this work, we wanted to continue these studies in order to understand the size effect of RN-induced cytotoxicity in MG-63 and HepG-2, two representative cancer cell lines. Furthermore, we wanted to reduce the $\mathrm{As}_{2} \mathrm{O}_{3}$ in $\mathrm{RN}$ by traditional processing and further study the effect of processing on antitumor activity and the side-effects of RN. 


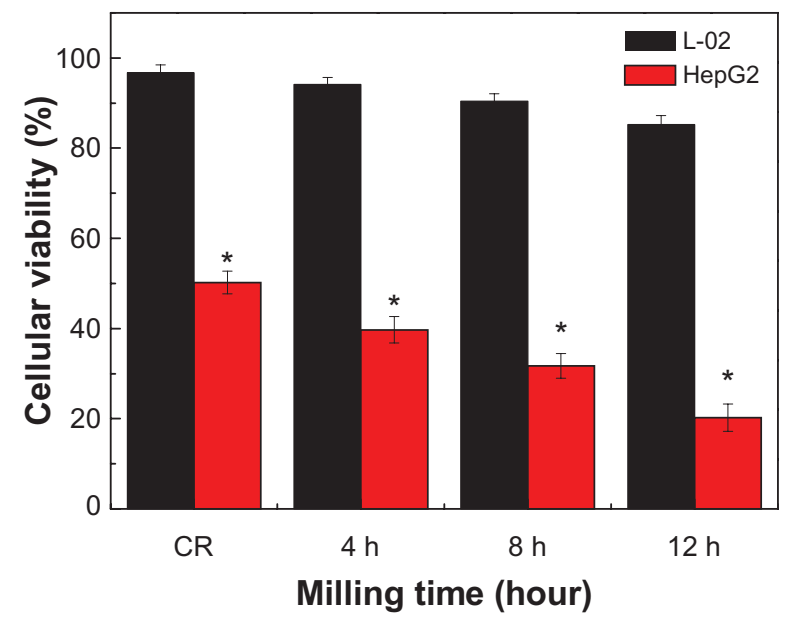

Figure 7 Cytotoxicity of the realgar milled for different times (4, 8, and 12 hours) and coarse realgar (CR) treatment in L-02 cells and HepG-2 cells for 72 hours and at a concentration of $400 \mu \mathrm{g} / \mathrm{mL}$ (compared with the L-02 group treated with the $\mathrm{RN}$ after milling for the same time).

Note: $* P<0.05$.

In this study, the widely used high-energy grinding technology with water-soluble surfactants was applied to scale down the particle size of realgar. The data showed that extending milling time within the initial 12 hours reduced the size of realgar. But after this time point, time had no apparent effect on particle size. It is well accepted that the milling process is an equilibrium process, in which the interaction process is affected by aggregation and dispersion processes. ${ }^{13,14}$ Within a certain period, the dispersion process is stronger than the reuniting process and the particle size declines as the time is increased. This resignation phase is followed by a balance phase. At this point in time, the rate of dispersion is equal to the rate of reuniting and the particle

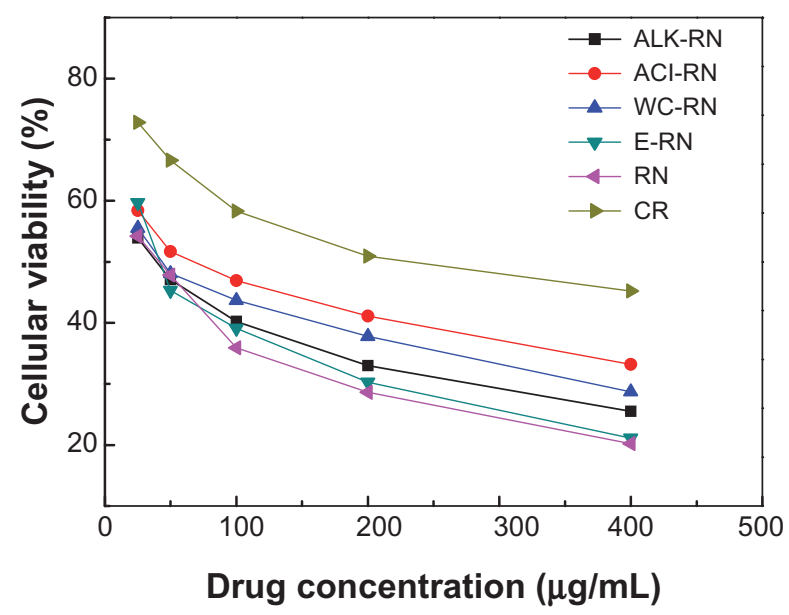

Figure 8 Cytotoxicity of the realgar nanoparticles (RN) after different processing treatment in HepG-2 cells for 72 hours' incubation. RN were added to the media: $400 \mu \mathrm{g} / \mathrm{mL}, 200 \mu \mathrm{g} / \mathrm{mL}, 100 \mu \mathrm{g} / \mathrm{mL}, 50 \mu \mathrm{g} / \mathrm{mL}, 25 \mu \mathrm{g} / \mathrm{mL}$.

Abbreviations: $\mathrm{ACl}$, acid cleaning; $\mathrm{ALK}$, alkali cleaning; $\mathrm{CR}$, control; $\mathrm{E}$, elutriation; $\mathrm{RN}$, realgar nanoparticle; WC, water cleaning.

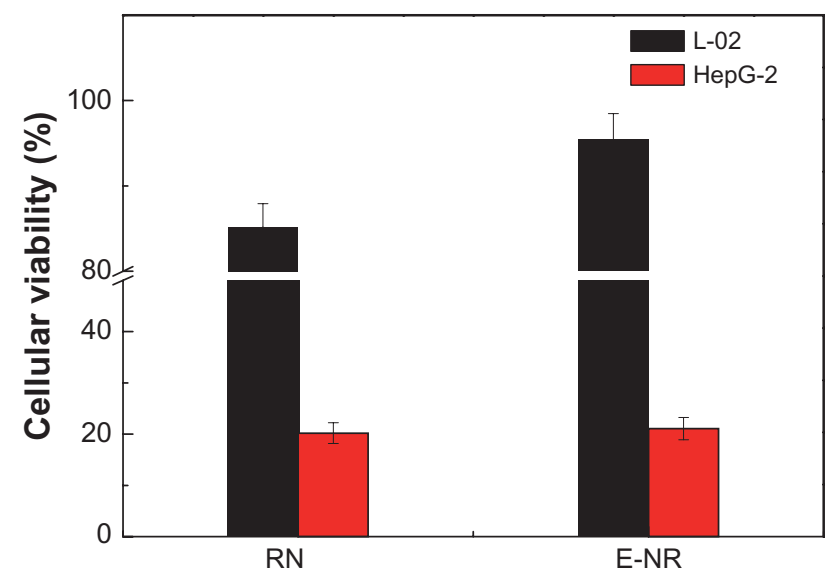

Different types of realgar nanoparticles

Figure 9 Cytotoxicity of the realgar nanoparticles (RN, milled for 12 hours) and $\mathrm{RN}$ treated by elutriation (E-RN) in L-02 cells and HepG-2 cells for 72 hour at a concentration of $400 \mu \mathrm{g} / \mathrm{mL}$.

size reaches the minimum. After the balance time point, the particle size enlarges again because the rate of dispersion is less than the rate of reuniting. On this premise, it can be inferred that 12 hours is the balance time point for realgar. Our data also showed that SDS, especially at the saturated concentration of $2.48 \mathrm{~g} / \mathrm{L}$, greatly contributed to the reduced size of realgar. We believe that this phenomenon could be attributed to effective wetting of the realgar surface, providing a steric and/or ionic barrier, and inhibition of recrystallization and/or aggregation of realgar particles in water.

The size reduction of realgar particles by high-energy milling is always accompanied by an increase in their number and by the generation of fresh, previously unexposed surface.

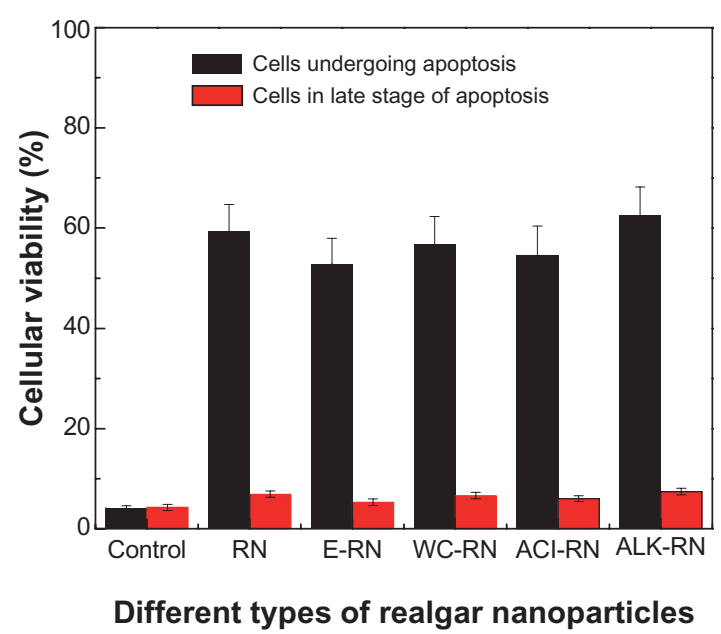

Figure 10 Comparison of the cell viabilities of HepG-2 cells treated with different types of realgar nanoparticles (RN) for 24 hours $(400 \mu \mathrm{g} / \mathrm{mL})$.

Abbreviations: $\mathrm{ACl}$, acid cleaning; ALK, alkali cleaning; $\mathrm{E}$, elutriation; $\mathrm{RN}$, realgar nanoparticle; WC, water cleaning. 
Therefore, in this study we compared the physicochemical properties of the RN before and after milling. XRD patterns and FITC spectra confirmed that after milling, the main phase and chemical composition were apparently unaltered. The results in Table 2 also showed that after milling, the zeta potential of the $\mathrm{RN}$ was reduced from almost zero to a negative value, probably because realgar is nonionizing. After grinding, negatively charged SDS was partially adsorbed onto the surface of the RN and thus the zeta potential values became negative.

In order to reduce the content of $\mathrm{As}_{2} \mathrm{O}_{3}$ in realgar, different processing methods applied in Chinese traditional medicine for thousands of years were used in this study. Data showed that, as expected, $\mathrm{As}_{2} \mathrm{O}_{3}$ content could be effectively reduced when treated by all processing methods except for alkali cleaning. The reason we conjectured is that the dilute caustic soda in solution might have reacted with $\mathrm{As}_{2} \mathrm{~S}_{2}$, thus resulting in the transformation of $\mathrm{As}_{2} \mathrm{~S}_{2}$ to $\mathrm{As}$ or $\mathrm{As}_{2} \mathrm{O}_{3}$. In contrast, the elutriation process produced the highest reduction in $\mathrm{As}_{2} \mathrm{O}_{3}$. The data obtained also indicated that there was only a marginal difference between the zeta potentials of RN treated by the different methods. Additionally, there was a slight difference in particle size between all $\mathrm{RN}$ processing methods except for elutriation. XRD and FTIR (data not shown) also showed that none of the processing methods had any clear effects on the main phase and chemical compositions.

The in vitro cytotoxicity test showed that, consistent with the previous investigations, ${ }^{6,715} \mathrm{RN}$ inhibited growth of the two selected tumor cell lines more significantly than CR, especially after 72 hours' incubation. Further, comparing the two tumor cell lines showed that HepG-2 cells were likely more sensitive than MG-63 cells. Meanwhile, by comparing the effects of realgar of various particle sizes on the cellular viability of the cancer cell lines and human normal cell lines, it can be concluded that the size of the realgar nanoparticles is the key element for the effect of antitumor activity. Also, $\mathrm{RN}$ of smaller size and higher $\mathrm{As}_{2} \mathrm{O}_{3}$ exhibited slight cytotoxicity to L- 02 .

The in vitro cytotoxicity results also indicated that, compared with $\mathrm{RN}$ without processing, $\mathrm{RN}$ cytotoxicities after processing decreased in the order of untreated RN $>$ ALKRN $>$ WC-RN $>$ ACI-RN $>$ E-RN. According to our study, the untreated RN, ALK-RN, WC-RN, and ACI-RN used here possessed similar phase and chemical composition, particle size, and zeta potential. Their cytotoxicity showed a similar trend with the content of $\mathrm{As}_{2} \mathrm{O}_{3}$. Based on these results, in can be hypothesized that $\mathrm{As}_{2} \mathrm{O}_{3}$ content had a predominant effect on RN cytotoxicity. E-RN, however, had the lowest $\mathrm{As}_{2} \mathrm{O}_{3}$ content and showed comparable cytotoxicity to untreated
$\mathrm{RN}$. We think this may be attributable to its smaller particle size. Previous investigations have asserted that particle size plays a critical role in the cellular uptake of nanoparticles and thereby their bioactivity. Cellular uptake of smaller nanoparticles is often greater than that of larger nanoparticles, especially when the size is $>100 \mathrm{~nm}$. Thus, although E-RN contained the lowest $\mathrm{As}_{2} \mathrm{O}_{3}$, it could induce the strongest cytotoxicity in HepG-2 cells. Further results indicated that, as expected, after elutriation the viability of L-02 was obviously increased, meaning a lessening of the side effects of $\mathrm{RN}$ after elutriation.

Apoptosis, or programmed cell death, is an important way to maintain cellular homeostasis between cell division and cell death. Dysregulation of apoptosis is linked to the development of most cancers. Thus, an induction of apoptosis in cancer cells is considered as a new focus in the discovery of anticancer drugs. So, in this study, to further understand RN-initiated cytotoxicity, we examined the possibility of apoptosis-induction by RN in HepG-2. The results confirmed that $\mathrm{RN}$ both before and after all processing treatments clearly induced apoptosis in HepG-2, especially the early stages of apoptosis.

\section{Conclusion}

In this study, RN were successfully produced by a ballmilling method with the assistance of SDS. RN with an average diameter of about $127 \mathrm{~nm}$ could be obtained after 12 hours milling at an SDS concentration of $2.48 \mathrm{~g} / \mathrm{L}$. Compared with $\mathrm{CR}$, the as-prepared $\mathrm{RN}$ exhibited a stronger antiproliferation effect on the HepG-2 and MG-63 cell lines, and the $\mathrm{RN}$-induced cytotoxicity was typically size-, concentration-, and time-dependent. Also, the RN cytotoxicities in the HepG2 and L-02 cells all increased as particle size was reduced. The processing methods, including water cleaning, acid cleaning, and alkali cleaning, all decreased $\mathrm{As}_{2} \mathrm{O}_{3}$ content, thus reducing cytotoxicity. But the $\mathrm{RN}$ treated by elutriation with the lowest $\mathrm{As}_{2} \mathrm{O}_{3}(3.5 \mathrm{mg} / \mathrm{g})$ and the smallest size $(109.3 \mathrm{~nm})$ exhibited comparable cytotoxicity in HepG-2 to untreated RN. Meanwhile, the side effects of RN were effectively reduced. Lastly, RN with or without processing can induce apoptosis in HepG-2 cells.

\section{Acknowledgment}

The authors acknowledge the financial support from Novel medicine foundation of Shanghai Science and Technology Commission (08DZ1972105), Shanghai Nanotechnology Special Foundation (No $0952 \mathrm{~nm}$ 05400), Fundamental Research Funds for the Central Universities and Program 
for Changjiang Scholars and Innovative Research Team in University (IRT0825).

\section{Disclosure}

The authors declare no conflicts of interest in this work.

\section{References}

1. Shim MJ, Kim HJ, Yang SJ, Lee IS, Choi HI, Kim T. Arsenic trioxide induces apoptosis in chronic myelogenous leukemia K562 cells: possible involvement of p38 MAP kinase. J Biochem Mol Biol. 2002;35: 377-383.

2. Ana-Maria Florea AM. Toxicity of alkylated derivatives of arsenic, antimony and tin: cellular uptake, cytotoxicity, genotoxic effects, perturbation of $\mathrm{Ca}^{2+}$ homeostasis and cell death. Shaker Verlag. 2005:145.

3. Griffin RJ, Williams BW, Park HJ, Song CW. Preferential action of arsenic trioxide in solid-tumor microenvironment enhances radiation therapy. Int J Radiat Oncol Biol Phys. 2005;61:1516-1522.

4. William TF Jr. Environmental chemistry of arsenic, 1st ed. New York: Marcel Dekker; 2002.

5. Lu DP, Wang Q. Current study of APL treatment in China. Int J Hematol. 2002;76:316-318

6. Wu JZ, Ho PC. Evaluation of the in vitro activity and in vivo bioavailability of realgar nanoparticles prepared by cryo-grinding. Eur J Pharm Sci. 2006;29:35-44.
7. Deng Y, Xu H. Size effects of realgar particles on apoptosis in a human umbilical vein endothelial cell line: EVC-304. Pharm Res. 2001;44: 513-518.

8. Zhang J, Zhang X, Ni Y, Yang X, Li H. Bioleaching of arsenic from medicinal realgar by pure and mixed cultures. Process Biochem. 2007; 42:1265-1271.

9. Robertson AJB. The development of ideas on heterogeneous catalysis: progress from Davy to Langmuir. Platinum Metals Rev. 2007;27:31-39.

10. Zhang P, Wang S, Hu X. Arsenic trioxide treated 72 cases of acute promyelocytic leukemia. Chin J Hematokl. 1996;17:58.

11. Soignet SL, Maslak P, Wang ZG. Complete remission after treatment of acute promyelocytic leukemia with arsenic trioxide. $N$ Engl J Med. 1998;339:1341-1348.

12. Lu DP, Qiu JY, Jiang B, et al. Tetra-arsenic tetra-sulfide for the treatment of acute promyelocytic leukemia: a pilot report. Blood. 2002;99: 3136-3143.

13. Ning N, Peng ZF, Yuan L, Gou BD, Zhang TL, Wang K. RN induce apoptosis and necrosis in leukemia cell lines K562 and HL-60 Zhong Guo Zhong Yao Za Zhi. 2005;30:136-140. Chinese.

14. Prentis RA, Lis Y, Walker SR. Pharmaceutical innovation by the seven UK-owned pharmaceutical companies (1964-1985). Br J Clin Pharmacol. 1988;25:387-396.

15. Baláž P, Fabián M, Pastorek M, Cholujová D, Sedlák J. Mechanochemical preparation and anticancer effect of realgar $\mathrm{As}_{4} \mathrm{~S}_{4}$ nanoparticles. Mater Lett. 2009;63:1542-1544.
International Journal of Nanomedicine

\section{Publish your work in this journal}

The International Journal of Nanomedicine is an international, peerreviewed journal focusing on the application of nanotechnology in diagnostics, therapeutics, and drug delivery systems throughout the biomedical field. This journal is indexed on PubMed Central, MedLine, CAS, SciSearch ${ }^{\circledR}$, Current Contents ${ }^{\circledR} /$ Clinical Medicine,

\section{Dovepress}

Journal Citation Reports/Science Edition, EMBase, Scopus and the Elsevier Bibliographic databases. The manuscript management system is completely online and includes a very quick and fair peer-review system, which is all easy to use. Visit http://www.dovepress.com/ testimonials.php to read real quotes from published authors. 